\title{
Antioxidative Properties of White and Red Flowered Agathi (Sesbania grandiflora) Tea and Tea Extracts
}

\section{Wijitra LIAOTRAKOON* and Vachiraya LIAOTRAKOON}

\author{
Department of Food Science and Technology, Faculty of Agricultural Technology and Agro-Industry, \\ Rajamangala University of Technology Suvarnabhumi, Phra Nakhon Si Ayutthaya 13000, Thailand
}

("Corresponding author's e-mail: L_wijitra@hotmail.com)

Received: 13 May 2017, Revised: 11 August 2018, Accepted: 20 September 2018

\begin{abstract}
The study aimed to examine the effect of agathi (Sesbania grandiflora) variety (i.e. red and white flower varieties), flower with and without pollen, and infusion times on the total phenol and tannin contents, and antioxidative activity (DPPH free radical scavenging and ferric reducing antioxidant power; FRAP) of agathi teas. The total phenol content, DPPH, and FRAP of the red flower agathi in form of dried tea were higher than those of the white variety $(p<0.05)$. The total phenol content of red and white flowered agathi teas were remained about 77 and $55 \%$, respectively (as dry basis weight) compared to the fresh flower agathi. In addition, the antioxidative activity of the agathi tea extracts significantly increased with increasing infusion time. The DPPH and FRAP of the tea extracts of flower agathi with pollen were slightly higher than those of the flower agathi without pollen tea extracts. After infusion the agathi tea with hot water $\left(95^{\circ} \mathrm{C}\right.$ ) for $10 \mathrm{~min}$ (time interval of $2 \mathrm{~min}$ ), total phenol content, DPPH, FRAP, and tannin content of the red flowered agathi with pollen were the highest among all flower agathi teas ( $p$ $<0.05$ ). Therefore, the agathi tea should be infused at $95{ }^{\circ} \mathrm{C}$ for $10 \mathrm{~min}$ to gain more bioactive compounds. The results indicated that the red flowered agathi tea had efficient antioxidative activity that they could be used as a potential source of natural antioxidants.
\end{abstract}

Keywords: Antioxidative properties, tannin, agathi, tea, tea extract

\section{Introduction}

Agathi (Sesbania grandiflora) is a common plant found in Asian countries, especially in India, Malaysia, and Thailand, and its flower and leave are normally consumed. It is adapted to both wet and dry regions of the tropics and is frost sensitive. It has large pea flowers which range in color from white and pink through to red. The flower agathi is rich in antioxidative properties as a result of polyphenols and flavonoids [1]. It has been reported that the red flowered agathi had high in anthocyanin content resulting in anti-inflammatory and antinociceptive activities [2]. Apart from its flower, the antioxidant compounds, such as gallic acid, caffeic acid, kaempferol, quercetin, and rutin, in agathi leaves were also found [3]. Hence, the antioxidant activity of the red flowered agathi were higher than that of the white flowered agathi because of the flower pigments, known as bioactive compounds such major phenolic compounds, to act as anti-cancer and anti-Alzheimer's [4].

Tea is one of the most widely consumed non-alcoholic beverages that rich in tannins, commonly referred to tannic acid, which are water-soluble polyphenol compounds. It is ordinary type from Camelia sinensis, however it could be made from edible stems, flowers and leaves of plants in forms of fresh and dried as herbal teas. They are consumed by infusion in boiling water to gain their fragrance, color and antioxidant properties [5-7]. Herbal teas could be considered as an alternative source of antioxidants to provide a health benefit due to polyphenol compounds present in plants like fruits and vegetables that 
http://wjst.wu.ac.th

could be applied as dietary supplements [8], such as stevia (Stevia rebaudiana), mulberry (Morus alba), safflower (Carthamus tinctorius), senna (Cassia angustifolia), roselle (Hibiscus sabdariffa), ginger (Zingiber officinale), and finger root (Boesenbergia rotunda) teas [9,10]. The polyphenol compounds present in herbal tea may act as antioxidant, antimicrobial, anticarcinogenic and antimutagenic. On the other hand, a high concentration of tannin is often considered as antinutritional by inhibition of digestive enzymes, and preventing in vitamin and mineral utilization [11,12]. In general, phenolic compounds, which consist of a hydroxyl group directly attached to an aromatic ring, are the most abundant antioxidative components in most plant-based foods. They have a wide variety of structures, such as simple phenolic, phenolic acid and polyphenolic, therefore they can exhibit different functions, e.g. coloring, sensory, and biological functions as bioactive components having health benefits [13,14].

In the recent years, the study of antioxidant activity of many herbal tea plants is still limited. Therefore, this research aimed to determine bioactive compounds (phenolic and tannin) and antioxidant activity (DPPH free radical scavenging and ferric reducing antioxidant power; FRAP) of 2 agathi $(S$. grandiflora) varieties, including white and red flower varieties, in forms of tea (dried flower agathi) and tea extracts (water-soluble extract).

\section{Materials and methods}

\section{Agathi tea processing}

Two varieties of mature flower agathi ( $S$. grandiflora), i.e. white and red flowered agathi, were collected from Phra Nakhon Si Ayutthaya, Thailand. The freshly collected plant materials were immediately clean, taken of the pollen (for the sample without pollen), washed thoroughly in running water and allowed to drain. After that, they were sliced into small pieces, placed on a tray and dehydrated in a cabinet tray drier at $60{ }^{\circ} \mathrm{C}$ until the weight remains constant, which were dried for $4 \mathrm{~h} 30 \mathrm{~min}$ to obtain dried flower agathi with roughly $13 \%$ moisture content. The agathi tea samples were then stored at $-18{ }^{\circ} \mathrm{C}$ in a dark container for determinations of total phenol content, tannin content, and antioxidant activity (namely DPPH and FRAP).

\section{Acceptance test of agathi teas}

The sensory evaluation of 4 developed agathi tea products (i.e., with and without pollen white and red flowered agathi) was carried out. One gram of each product was infused in hot water $\left(95 \pm 2{ }^{\circ} \mathrm{C}\right)$. Sensory evaluation was done at room temperature with ambient light by 30 panelists. Five attributes were evaluated (i.e., color, flavor, taste, after-taste, and overall acceptability) using a 9-point hedonic scale where 1 meaning dislike extremely, 2 meaning dislike much, 3 meaning dislike moderately, 4 meaning dislike slightly, 5 meaning neither dislike nor like, 6 meaning like slightly, 7 meaning like moderately, 8 meaning like much, and 9 meaning like extremely.

\section{Preparation of agathi tea infusions}

The effect of infusion time on antioxidative properties of agathi teas was examine as following; 4 types of agathi teas (i.e., with and without pollen white and red flowered agathi) were prepared by taking $1 \mathrm{~g}$ of tea sample in a sealed tea bag into $200 \mathrm{ml}$ hot water $\left(95 \pm 2{ }^{\circ} \mathrm{C}\right)$ to provide water-soluble tea extracts. After that, the tea extracts were collected for $0,2,4,6,8$ and $10 \mathrm{~min}$ in triplicate, and infusions were allowed for $15 \mathrm{~min}$ with constant stirring. Tea extracts were filtered using Whatman No. 1 filter paper, and stored at $-18{ }^{\circ} \mathrm{C}$ in a dark place for antioxidative property determinations, namely total phenolic content, total tannin content and antioxidant activity (DPPH and FRAP) of tea extract samples.

\section{Extraction for antioxidant activity determinations}

The extracts for antioxidative property determinations were prepared as following; the agathi tea and water-soluble tea extracts were extracted with chilled $80 \%$ acetone solution in a blender for 10 min to mainly contain the extraction of polar compounds. The slurry was vacuum-filtered over a Whatman no. 1 filter paper [modified from 15,16]. The extracts were stored in dark at $-18{ }^{\circ} \mathrm{C}$ for further analysis. The 
http://wjst.wu.ac.th

analyses of aqueous acetone extracts were done in triplicate, and the chemical for determination might be freshly prepared.

\section{Total phenol content analysis}

The Folin-Ciocalteu's reagent was used for total phenol content determination [17]. A $0.3 \mathrm{ml}$ of aqueous acetone extract was added to $1.5 \mathrm{ml}$ of Folin-Ciocalteu's reagent and $1.2 \mathrm{ml}$ of $7.5 \%$ sodium carbonate. After vortexing, the samples stabilised for $30 \mathrm{~min}$ at room temperature, and the total phenol content was determined by using a spectrophotometer at a wavelength of $765 \mathrm{~nm}$. The standard curve was prepared using solutions of gallic acid (GA) and then total phenol content is expressed as mg GA equivalents in the sample.

\section{DPPH free radical scavenging activity analysis}

The DPPH assay can be used to determine the free radical scavenging capacity of the sample. A 4 $\mathrm{ml}$ of $80 \%$ ethanolic $0.6 \mathrm{mM}$ of DPPH (2,2-diphenyl-1-picrylhydrazyl) solution was mixed with $1 \mathrm{ml}$ of the extract. The absorbance was measured at $515 \mathrm{~nm}$ after standing for $3 \mathrm{~h}$ (modified from [14]). The series of GA solutions were prepared for the standard curve, and DPPH value is expressed in mg GA equivalents in the sample.

\section{Ferric reducing antioxidant power (FRAP) analysis}

The FRAP determination of the extracts was determined according to the method of Lim et al. [17]. A $1 \mathrm{ml}$ of the extract was mixed with $2.5 \mathrm{ml} 0.2 \mathrm{M}$ phosphate buffer at $\mathrm{pH} 6.6$ and $2.5 \mathrm{ml} 1 \%$ potassium ferricyanide. The mixtures were incubated in a water bath at $50{ }^{\circ} \mathrm{C}$ for $20 \mathrm{~min}$, and then $2.5 \mathrm{ml} 10 \%$ trichloroacetic acid was added. After that, $2.5 \mathrm{ml}$ of the mixture was taken, and $2.5 \mathrm{ml}$ distilled water and $0.5 \mathrm{ml} 1 \% \mathrm{FeCl}_{3}$ was added. The absorbance at $700 \mathrm{~nm}$ was measured after standing for $30 \mathrm{~min}$ at room temperature.

\section{Total tannin content analysis}

Total tannin content was examined by Folin-Ciocalteu's method with tannic acid as reference (adapted from [18]). A $0.2 \mathrm{ml}$ of extract was added to a mixture of $2.5 \mathrm{ml}$ of distilled water, $0.2 \mathrm{ml}$ of Folin-Ciocalteu's reagent and $2 \mathrm{ml}$ of $7 \% \mathrm{Na}_{2} \mathrm{CO}_{3}$. After vortexing, the samples stand for $30 \mathrm{~min}$, and the total tannin content was determined by using an UV/Visible spectrophotometer at a wavelength of 700 $\mathrm{nm}$. The standard curve was prepared using solutions of tannic acid and the results were expressed in $\mathrm{mg}$ tannic acid equivalents.

\section{Statistical analysis}

In the study, the data obtained from 3 replications were analyzed and shown as mean \pm standard deviation (SD). The significant differences among means of all treatments were subjected to analysis of variance (ANOVA), and the confidence limits used in this study were based on $95 \%(p<0.05)$.

\section{Results and discussion}

The antioxidative properties of the white and red flowered agathi tea

The untreated white and red flowered agathi samples were subjected to determine the antioxidative properties, and the results illustrate in Figure 1. The moisture content of all flower agathi samples was comparable values (about $90 \%$ ). Total phenol and tannin contents, and antioxidative properties (DPPH and FRAP) of the fresh red flowered agathi were significantly higher than those of the white variety $(p<$ 0.05). The DPPH of red flowered agathi was 3.4 times higher than that of the white flowered agathi, and the FRAP values of untreated white and red flowered agathi samples were 0.51 and 1.68 , respectively. According to the results, a high antioxidant activity in the red flowered agathi might be due to it contain phytochemical compounds, such as phenolic compounds, flavonoids and anthocyanins, etc., which have the ability to neutralize free radicals, resulting in many disease prevention and health promotion $[1,2]$. The results indicated that flower agathi could be considered as a potential antioxidant activity source like 
http://wjst.wu.ac.th

found in some edible flowers, such as Curcuma sessilis Gage, Dolichandrone serrulata (DC.) Seem, and Telosma minor Craib. [19]. It was also found that flower of Tupistra albiflora K. Larsen showed remarkable antioxidant properties due to high content of essential oils, and rich in nutritional values such as protein, thiamin, riboflavin, and pyridoxine [20].

(a)

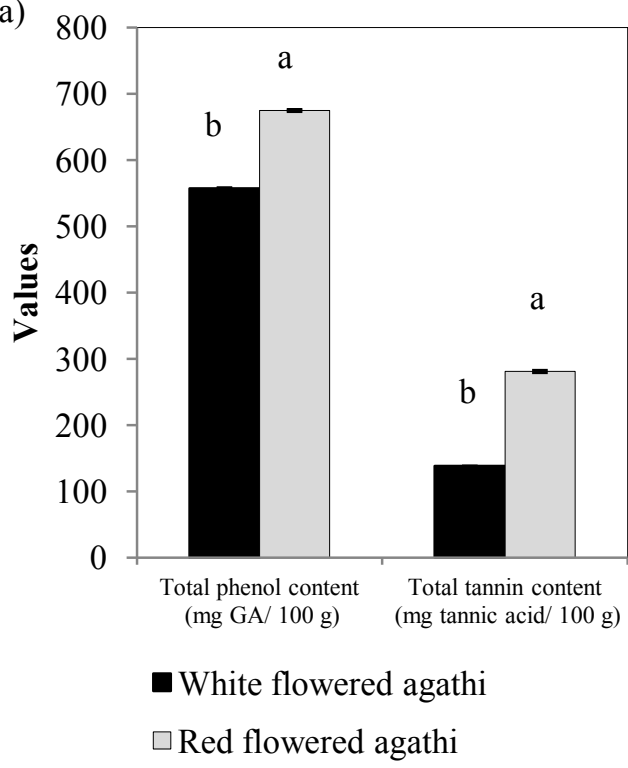

(b)

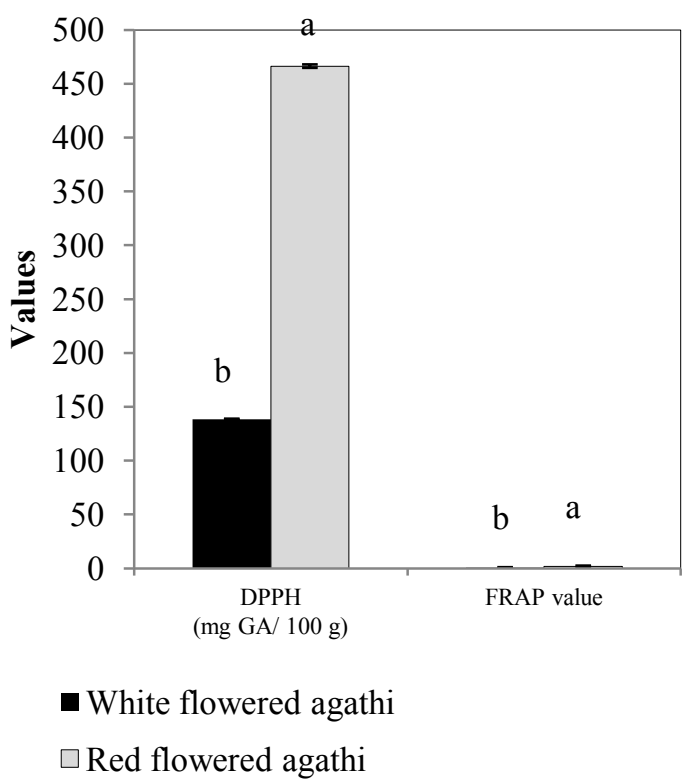

Figure 1 The antioxidative properties of the untreated white and red flowered agathi (dry basis weight); (a) total phenol and tannin contents, and (b) DPPH free radical scavenging method and ferric reducing antioxidant power (FRAP) values.

In the study, 4 samples of flower agathi, i.e. the white flowered agathi with pollen, the white flowered agathi without pollen, the red flowered agathi with pollen, and the red flowered agathi without pollen, were dried at $60{ }^{\circ} \mathrm{C}$ for $4 \mathrm{~h} 30 \mathrm{~min}$ to obtain the dried flowered agathi, which referred as agathi teas. The bioactive compounds of the dried agathi were examined, and the results show in Table 1. The moisture content of all flower agathi samples decreased from about 90 to $13 \%$ after drying. Total phenol and tannin contents, and antioxidative properties (DPPH and FRAP) of the red flowered agathi tea were significantly higher than those of the white variety $(p<0.05)$. The higher FRAP value indicates an increasingly of the reducing power. The agathi teas with higher phenol content had stronger antioxidant activities. In addition, the antioxidative properties of the flower agathi with pollen tea were also slightly higher than those of the flower agathi without pollen tea. After drying, the total phenol content of the white and red flowered agathi tea remained up to 54.58 and $76.56 \%$, respectively, compared to the fresh agathi (dry basis). However, the total phenolic content of the red flowered agathi tea (516.56 - 562.53 mg GA/ $100 \mathrm{~g}$, dry basis) had much higher than finger root (B. rotundas) tea (190 mg GA/ $100 \mathrm{~g})$, whereas it had slightly lower than roselle (H. sabdariffa) tea $(660 \mathrm{mg}$ GA/ $100 \mathrm{~g})$ [10]. These teas could be considered as herbal teas having antioxidant activities. This finding is in agreement with Siddhuraju et al. [21]. The drying temperature is also important to control the product quality to maintain the antioxidant activity. However, it has been reported that the antioxidant activities of the $C$. sinensis teas had much higher than some fresh vegetables, such as broccoli flowers, red bell pepper, onion, corn, sweet potato, and carrot [22]. In addition, Jung et al. [23] found that the antioxidant properties of dried persimmon decreased compared to the fresh persimmons through a drying [24]. In conclusion, the major results in 
http://wjst.wu.ac.th

this study indicated that flower agathi showed a high content of polyphenols, having antioxidant potential. Apart from agathi tea, the flower agathi might be useful in dietary supplement for food applications, such as bakery products (i.e. cookie and bread).

Table 1 The antioxidative properties of the white and red flowered agathi tea (dry basis weight).

\begin{tabular}{lllll}
\hline \multirow{2}{*}{ Agathi tea } & \multicolumn{3}{c}{ Antioxidative properties } \\
\cline { 2 - 5 } & $\begin{array}{l}\text { Total phenol content } \\
\text { (mg GA/ 100 g) }\end{array}$ & $\begin{array}{l}\text { DPPH } \\
\text { (mg GA/ 100 g) }\end{array}$ & $\begin{array}{l}\text { FRAP } \\
\text { value }\end{array}$ & $\begin{array}{l}\text { Total tannin content } \\
\text { (mg tannic acid/ 100 g) }\end{array}$ \\
\hline $\begin{array}{l}\text { White flowered agathi tea } \\
\text { With pollen }\end{array}$ & $318.80 \pm 3.88^{\mathrm{c}}$ & $22.30 \pm 0.15^{\mathrm{b}}$ & $1.12 \pm 0.05^{\mathrm{c}}$ & $19.41 \pm 0.28^{\mathrm{b}}$ \\
$\begin{array}{l}\text { Without pollen } \\
\text { Red flowered agathi tea }\end{array}$ & $304.62 \pm 4.85^{\mathrm{d}}$ & $12.71 \pm 0.49^{\mathrm{c}}$ & $0.88 \pm 0.01^{\mathrm{d}}$ & $15.40 \pm 0.16^{\mathrm{c}}$ \\
& & & & \\
With pollen & $562.53 \pm 4.28^{\mathrm{a}}$ & $28.78 \pm 0.07^{\mathrm{a}}$ & $1.52 \pm 0.05^{\mathrm{a}}$ & $20.79 \pm 0.31^{\mathrm{ab}}$ \\
Without pollen & $516.56 \pm 5.44^{\mathrm{b}}$ & $28.72 \pm 0.04^{\mathrm{a}}$ & $1.37 \pm 0.02^{\mathrm{b}}$ & $19.85 \pm 0.21^{\mathrm{b}}$ \\
\hline
\end{tabular}

Values are means of triplicate measurements \pm SD $(n=3)$ and the superscripts with the different letters within the same column are significantly different $(p<0.05)$.

The acceptance test of the white and red flowered agathi tea

The acceptance of tea extracts of white flowered agathi with pollen, the white flowered agathi without pollen, the red flowered agathi with pollen, and the red flowered agathi without pollen after infusion in hot water were examined by sensory evaluation. The sensory scores (9-hedonic scale) of these water-soluble agathi tea extracts are shown in Table 2. It was found that tea from both varieties of flower agathi was preferred in terms of color, flavor, taste, after-taste and overall acceptability of the tea, which the panelists like the products moderately (scores were between 6.38 and 7.26). The sensory score of all attributes of 4 products were not significantly different $(p>0.05)$. This indicates that agathi tea with pollen was also preferred, even the pollen of the agathi flower is bitter. For color attribute, the red flowered agathi showed the reddish color due to the presence of anthocyanins, which is a water-soluble compound, and brilliantly red-purple pigments.

Table 2 The sensory score of the water-soluble white and red flowered agathi tea extracts.

\begin{tabular}{|c|c|c|c|c|c|}
\hline \multirow[b]{2}{*}{ Agathi tea extract } & \multicolumn{5}{|c|}{ Sensory score } \\
\hline & Color $^{\text {ns }}$ & Flavor ${ }^{n s}$ & Taste $^{\mathrm{ns}}$ & After-taste $^{\mathrm{ns}}$ & $\begin{array}{l}\text { Overall } \\
\text { acceptability }^{\text {ns }}\end{array}$ \\
\hline \multicolumn{6}{|l|}{ White flowered agathi tea } \\
\hline With pollen & $6.76 \pm 1.33$ & $6.74 \pm 1.12$ & $6.46 \pm 1.36$ & $6.40 \pm 1.50$ & $6.68 \pm 1.19$ \\
\hline Without pollen & $6.88 \pm 1.29$ & $6.66 \pm 1.35$ & $6.60 \pm 1.31$ & $6.52 \pm 1.45$ & $6.70 \pm 1.22$ \\
\hline \multicolumn{6}{|l|}{ Red flowered agathi tea } \\
\hline With pollen & $7.10 \pm 1.05$ & $6.94 \pm 1.11$ & $6.38 \pm 1.29$ & $6.70 \pm 1.43$ & $6.82 \pm 1.02$ \\
\hline Without pollen & $7.26 \pm 1.21$ & $6.86 \pm 1.14$ & $6.78 \pm 1.25$ & $6.68 \pm 1.36$ & $7.02 \pm 1.13$ \\
\hline
\end{tabular}


(a)

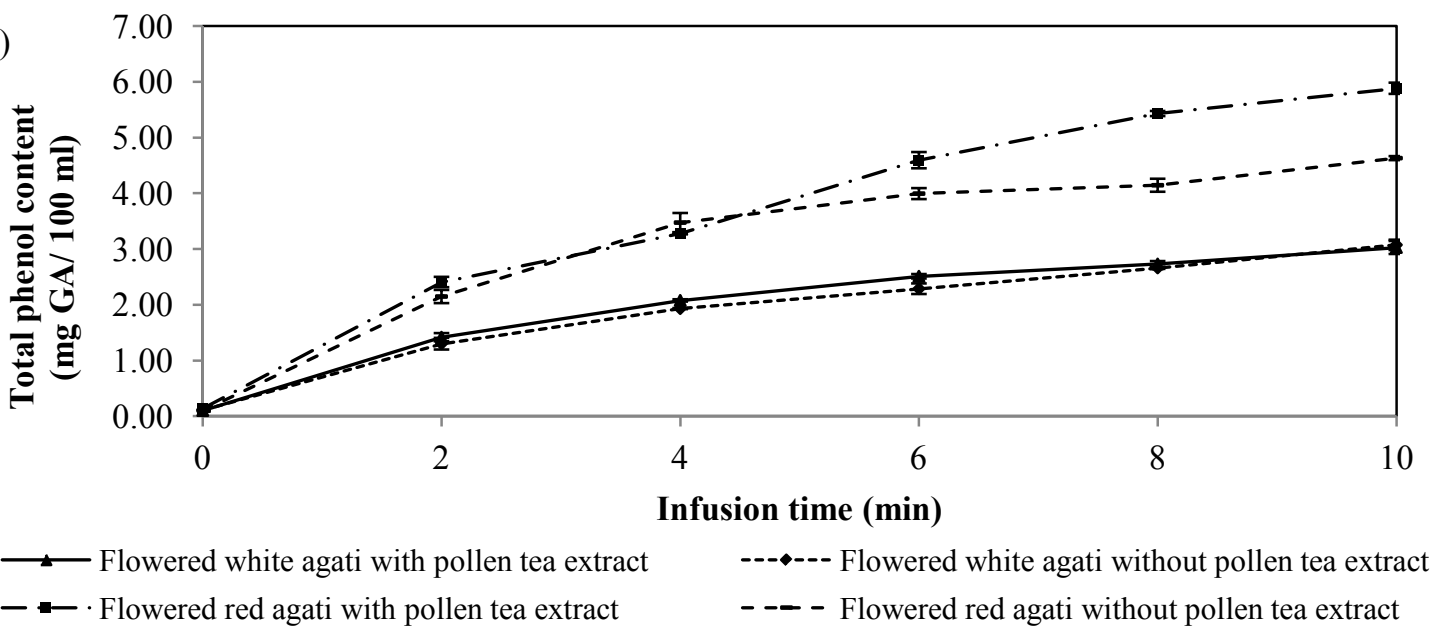

(b)

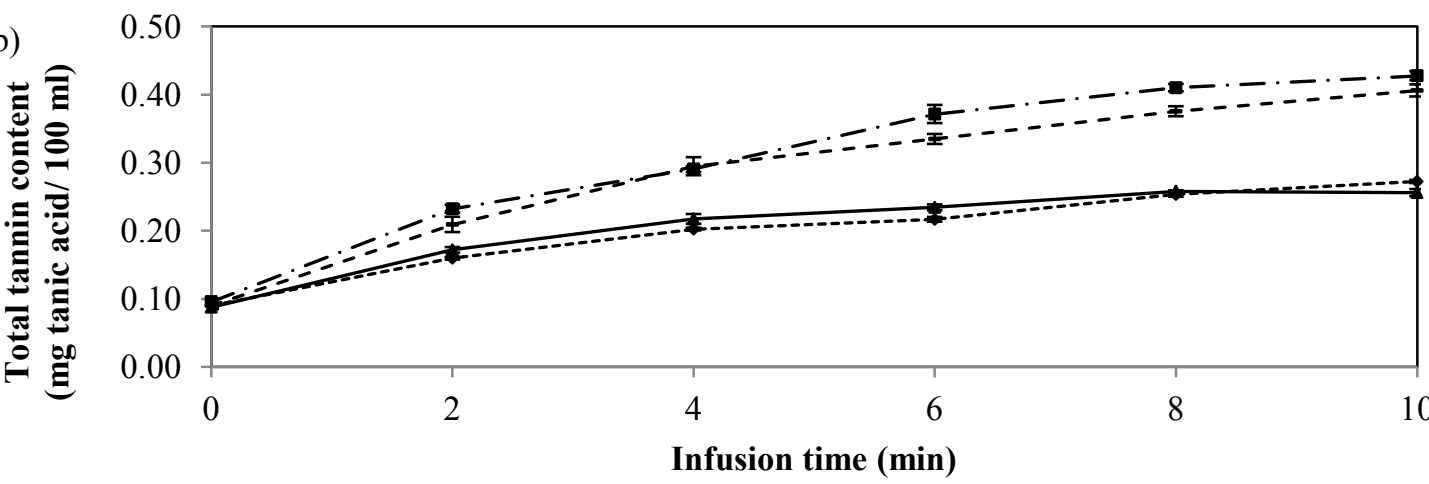

$\longrightarrow$ Flowered white agati with pollen tea extract

----- Flowered white agati without pollen tea extract

- - - Flowered red agati without pollen tea extract

Figure 2 The influence of different infusion times on (a) total phenol content and (b) total tannin content of the white and red flowered agathi tea extract.

Effect of infusion times on the changes of antioxidative properties of the white and red flowered agathi tea extract

Four tea samples (i.e., the white flowered agathi with pollen, the white flowered agathi without pollen, the red flowered agathi with pollen, and the red flowered agathi without pollen teas) were infused in hot water at $95{ }^{\circ} \mathrm{C}$ for $10 \mathrm{~min}$, collected the extract samples every $2 \mathrm{~min}$, and determined the antioxidative properties of the flower agathi tea extracts. Total phenol and tannin contents of these 4 samples are shown in Figure 2, and the antioxidant activity (DPPH and FRAP) of studied agathi tea extracts are illustrated in Figure 3. Total phenol, tannin content, DPPH and FRAP of the tea extracts of both agathi varieties significantly increased when infusion time longer. After infusion for $10 \mathrm{~min}$, these antioxidative properties of all samples were the highest $(p<0.05)$. This indicates that the infusion time affected bioactive compounds in tea extract. The high antioxidative properties in the red agathi tea extract were also observed compared to that of the white agathi tea extract. Hence, the antioxidative properties in the flower agathi with pollen tea extract were slightly higher than in the tea extract without pollen.

In addition, total tannin content of the red flower agathi for $10 \mathrm{~min}$ of infusion contained about 4 times higher compared to the initial infusion time (Figure 2(b)). The finding results are in good 
agreement with the results of Rehman et al. [25] that the content of tannin, which could be found in tea extract because they are water-soluble polyphenols, of tea extract increased with an increase in boiling time. However, the excess content of tannin might course in decrease in sensory properties and also act as antinutritional.
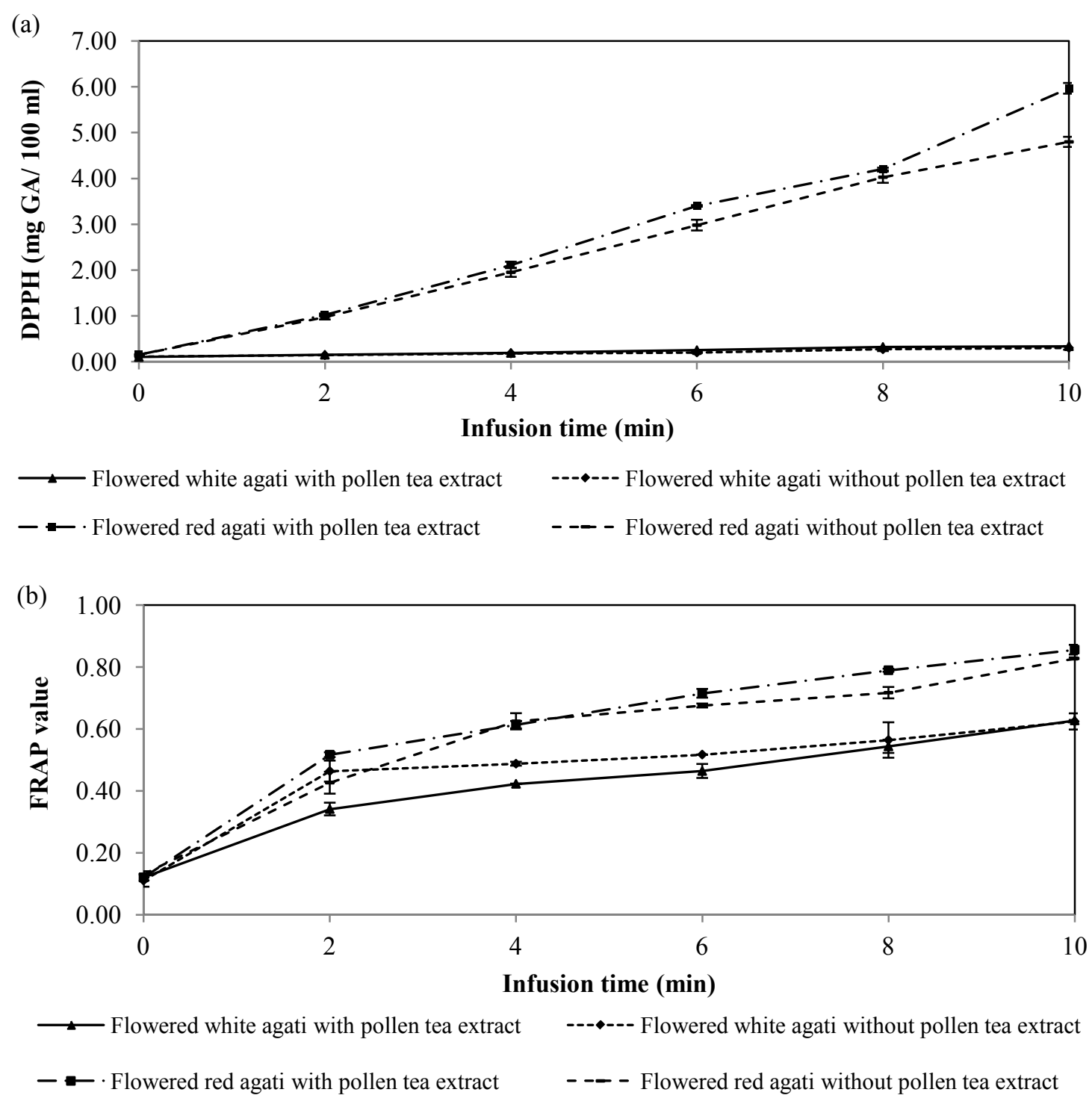

Figure 3 The influence of different infusion times on antioxidant activity by using (a) DPPH free radical scavenging method and (b) ferric reducing antioxidant power (FRAP) assay of the white and red flowered agathi tea extract. 
http://wjst.wu.ac.th

\section{Conclusions}

The bioactive compounds of the tea made from 2 flower agathi ( $S$. grandiflora) varieties, i.e. white and red flowered agathi were significantly observed. An excellent antioxidant activity and a high content of bioactive compounds were found in the untreated and dried (referred to the flower agathi tea) of the red flowered agathi, particularly in the flower agathi with pollen. Hence, the infusion time affected bioactive compounds and antioxidant activity in the water-soluble flowered agathi tea extract. Total phenol content, tannin content, DPPH and FRAP of all samples of water-soluble flowered agathi tea extracts gradually increased when infusion time longer. Therefore, the flower agathi tea, especially the red flowered agathi with pollen tea, could be recommended as a healthy beverage.

\section{Acknowledgments}

Financial support by Rajamangala University of Technology Suvarnabhumi is acknowledged as well as Department of Food Science and Technology, Faculty of Agricultural Technology and Agro-Industry, Rajamangala University of Technology Suvarnabhumi for the laboratory's facilities.

\section{References}

[1] S Gowri and K Vasantha. Antioxidant activity of Sesbania grandiflora (pink variety) L. Pers. Int. J. Eng. Sci. Technol. 2010; 2, 4350-6.

[2] N Loganayaki, N Suganya and S Manian. Evaluation of edible flowers of agathi (Sesbania grandiflora L. Fabaceae) for in vivo anti-inflammatory and analgesic, and in vitro antioxidant potential. Food Sci. Biotechnol. 2012; 21, 509-17.

[3] S Gowri. Free radical scavenging and antioxidant activity of leaves from agathi (Sesbania grandiflora) (L.) Pers. Am. Eur. J. Sci. Res. 2010; 5, 114-9.

[4] O Huabbangyang, M Buanong, C Wongs-Aree, C Techavutthiporn and V Srilaong. Study of nutritional and free radical scavenging activity in edible flowers (in Thai). Agr. Sci. J. 2010; 41, 381-4.

[5] R Manteiga, DL Park and SS Ali. Risks associated with consumption of herbal teas. Rev. Environ. Contam. Toxicol. 1997; 150, 1-30.

[6] V Naithani, S Nair and P Kakkar. Decline in antioxidant capacity of Indian herbal teas during storage and its relation to phenolic content. Food Res. Int. 2006; 39, 176-81.

[7] H Aoshima, S Hirata and S Ayabe. Antioxidative and anti-hydrogen peroxide activities of various herbal teas. Food Chem. 2007; 103, 617-22.

[8] H Speisky, C Rocco, C Carrasco, EA Lissi and C López-Alarcón. Antioxidant screening of medicinal herbal teas. Phytother. Res. 2006; 20, 462-7.

[9] ECW Chiang, LP Yan and TL Ngar. Analysis and evaluation of antioxidant properties of Thai herbal teas. Int. J. Adv. Sci. Arts 2011; 2, 8-15.

[10] N Chomchalow and A Hicks. Health potential of Thai traditional beverages. Assumption Univ. J. Tech. 2001; 5, 20-30.

[11] KT Chung, T Wong, C Wei, Y Huang and Y Lin. Tannins and human health: A review. Crit. Rev. Food Sci. Nutr. 1998, 38, 421-64.

[12] Y Ushir, A Luha, S Abhang and K Vadalia. Estimation of secondary metabolites in different tea and coffee brands from Indian market. Int. J. Pharm. Life Sci. 2011, 2, 599-600.

[13] I Ignat, I Volf and VI Popa. A critical review of methods for characterisation of polyphenolic compounds in fruits and vegetables. Food Chem. 2011; 126, 1821-35.

[14] R Nagasaka, C Chotimarkorn, IM Shafiqul, M Hori, H Ozaki and H Ushio. Anti-inflammatory effects of hydroxycinnamic acid derivatives. Biochem. Biophys. Res. Commun. 2007; 358, 615-9.

[15] K Mahattanatawee, JA Manthey, G Luzio, ST Talcott, K Goodner and EA Baldwin. Total antioxidant activity and fiber content of select Florida-grown tropical fruits. J. Agr. Food Chem. 2006; 54, 7355-63. 
http://wjst.wu.ac.th

[16] LC Wu, HW Hsu, YC Chen, CC Chiu, YI Lin and JAA Ho. Antioxidant and antiproliferative activities of red pitaya. Food Chem. 2006; 95, 319-27.

[17] YY Lim, TT Lim and JJ Tee. Antioxidant properties of several tropical fruits: A comparative study. Food Chem. 2007; 103, 1003-8.

[18] BR Rajesh, VP Potty and SG Sreelekshmy. Study of total phenol, flavonoids, tannin contents and phytochemical screening of various crude extracts of Terminalia catappa leaf, stem bark and fruit. Int. J. Appl. Pure Sci. Agr. 2016; 2, 291-6.

[19] P Siritrakulsak, P Chutichudet, B Chutichudet, M Plainsirichai and K Boontiang. Antioxidant activity of fifteen edible flowers in Maha Sarakham province (in Thai). Kaen Kaset Agr. J. 2013; 41, 607-11.

[20] N Chaichana. Nutritional composition, antioxidant activity and phytochemical composition of Tupistra albiflora K. Larsen's flowers. Walailak J. Sci. \& Tech. 2018; 15, 305-11.

[21] P Siddhuraju, A Abirami, G Nagarani and M Sangeethapriya. Antioxidant capacity and total phenolic content of aqueous acetone and ethanol extract of edible parts of Moringa oleifera and Sesbania grandiflora. Int. J. Biol. Biomol. Agr. Food Biotech. Eng. 2014; 8, 1090-8.

[22] G Cao, E Sofic and RL Prior. Antioxidant capacity of tea and common vegetables. J. Agric. Food Chem. 1996; 44, 3426-31.

[23] ST Jung, YS Park, Z Zachwieja, M Folta, H Barton, J Piotrowicz, E Katrich, S Trakhtenberg and S Gorinstein. Some essential phytochemicals and the antioxidant potential in fresh and dried persimmon. Int. J. Food Sci. Nutr. 2005; 56, 105-13.

[24] T Katsube, T Yoko, M Sugiyama, T Furuno and Y Yamasaki. Effect of air-drying temperature on antioxidant capacity and stability of polyphenolic compounds in mulberry (Morus alba L.) leaves. Food Chem. 2009; 113, 964-9.

[25] SU Rehman, K Almas, N Shahzadi, N Bhatti and A Saleem. Effect of time and temperature on infusion of tannins from commercial brands of tea. Int. J. Agri. Biol. 2002; 4, 285-7. 